\title{
Karyotype asymmetry shapes diversity within the physaloids (Physalidinae, Physalideae, Solanaceae)
}

Julieta Rodríguez ${ }^{\mathrm{a}, \mathrm{b}}$, Rocío Deanna ${ }^{\mathrm{b}, \mathrm{c}, \mathrm{d}}$, Franco Chiarini ${ }^{\mathrm{a}, \mathrm{b}}$

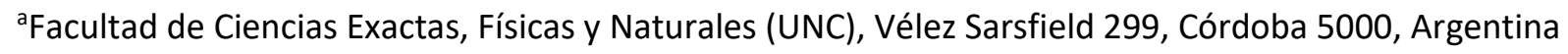

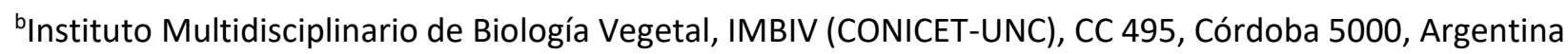

'Department of Ecology and Evolutionary Biology, University of Colorado, Boulder, CO, 80305, United States

${ }^{\mathrm{d} F a c u l t a d}$ de Ciencias Químicas (UNC), Medina Allende s.n., Córdoba 5000, Argentina

\begin{abstract}
Within the cosmopolitan family Solanaceae, Physalideae is the tribe with the highest generic diversity (30 genera and more than 200 species). This tribe embraces subtribe Physalidinae, in which positions of some genera are not entirely resolved. Chromosomes may help on this goal, by providing information on the processes underlying speciation. Thus, cytogenetic analyses were carried out in the subtribe in order to establish its chromosome number and morphology. Physalidinae is characterized by $\mathrm{x}=12$ and most species shows a highly asymmetric karyotype. These karyotype traits were mapped onto a molecular phylogeny to test the congruence between karyotype evolution and clade differentiation. A diploid ancestor was reconstructed for the subtribe, and five to six polyploidy independent events were estimated, plus one aneuploidy event ( $\mathrm{X}=11$ in the monotypic genus Quincula). Comparative phylogenetic methods showed that asymmetry indices and chromosome arm ratio $(r)$ have a high phylogenetic signal, whereas the number of telocentric and submetacentric chromosomes presented a conspicuous amount of changes. Karyotype asymmetry allow us to differentiate genera within the subtribe. Overall, our study suggests that Physalidineae diversification has been accompanied by karyotype changes, which can be applied to delimit genera within the group.
\end{abstract}

Keywords Asymmetry, Chromosome evolution, Karyotype, Physalidinae, Solanaceae

\section{Introduction}

Solanaceae, a cosmopolitan family of recognized economic and floristic importance, comprises 90-100 genera and 2400-3000 species (Olmstead \& Bohs, 2006; Barboza et al.,2016). The tribe with the greatest number of genera is Physalideae, which includes more than 200 species (Olmstead et al., 2008). According to molecular phylogenetics studies (Olmstead et al., 2008; Särkinen, Bohs, Olmstead \& Knapp, 2013), clades corresponding to the lochrominae and Physalidinae subtribes of Physalideae have high supports (Olmstead et al., 2008; Särkinen et al., 2013), but the subtribe Withaninae and the subtribal position of some genera are not entirely resolved (Smith \& Baum, 2006; Li, Gui, Xiong \& Averett, 2013; Särkinen et al., 2013). Recently, a new phylogenetic hypothesis of Physalideae has been proposed, increasing sampling to $73 \%$ of 
its species (Deanna, Larter, Barboza \& Smith, 2019), which allows the analysis of evolutionary patterns and the proposal of taxonomic rearrangements.

Cytogenetics provides a valuable and irreplaceable source of information to address taxonomic, evolutionary and applied problems (Poggio, 1996; Guerra, 2012). Patterns and mechanisms of karyotypic evolution may explain diversification and speciation processes through the comparison of the chromosomes of different taxa (Weiss Schneeweiss \& Schneeweiss, 2013). However, most of the cytogenetic information available from taxa belonging to Physalideae is restricted to reports of chromosome numbers and meiotic studies. This tribe has a basic number $X=12$ (Badr, Khalifa, Aboel-Atta \& Abou-El-Enain, 1997; Rego, da Silva, Torezan, Gaeta \& Vanzela, 2009; Barboza, Chiarini \& Stehmann, 2010; Chiarini, Moreno, Barboza \& Bernardello, 2010; Deanna, Barboza \& Scaldaferro, 2014), except for Quincula Raf. with X = 11 (Menzel, 1950). Many members of Physalideae have a meiotic chromosome number $n=12$ (Moscone, 1992; Bohs, 2005; Sousa Peña, 2001), while Withania Pauquy, Nothocestrum A. Gray, Tubocapsicum Makino and some species of Chamaesaracha (A. Gray) Benth. and Physalis L. are polyploid, with meiotic numbers of either $n=24$ or $n=36$ (Menzel, 1950, 1951; Averett, 1973;Deanna et al., 2018).

Polyploidy is a common phenomenon in plants that occurs naturally and spontaneously, consisting of the increase in genome size caused by the presence of three or more chromosome sets (Otto \& Whitton, 2000). This provides an important avenue for the evolution and generation of plant species (Winchester, 1981; Futuyma, 2005; Ranney, 2006; Thorpe, González Barrera \& Rothstein, 2007; Hegarty \& Hiscock, 2008; Maxime, 2008; Madlung, 2013). The ploidy level is an important factor to consider in crop improvement programs (Udall \& Wendel, 2006). Indeed, there are studies on populations of cultivated cape gooseberry ( $P$. peruviana L.) with $2 \mathrm{n}$ $=24,36$ and 48 (Rodríguez \& Bueno, 2006). Chromosome counts in more Physalideae members are necessary to increase knowledge about the frequency and distribution of polyploidy events in the group.

The chromosome morphology (i.e., karyotype) usually shows variability, mainly regarding to five different characteristics: (1) absolute size of the chromosomes, (2) centromere position, (3) relative chromosomes size, (4) basic number, and (5) number and position of the satellite (Stebbins, 1971). A symmetrical karyotype is one in which the chromosomes are approximately the same size and have a centromere which is in the middle position or slightly located towards one end. Increased asymmetry can occur through the change of the centromere position from the middle to the terminal position, or through the accumulation of differences in the relative size between the chromosome complement, thus yielding a more heterogeneous karyotype. These two trends are not necessarily correlated with each other, although they may be present in some groups (Stebbins, 1971). So far, karyoevolutive analyses in Physalideae have shown high variability in chromosome asymmetry between the subtribes, being the arm ratio $(r)$ considered the chromosome trait with the greatest phylogenetic signal (i.e., degree of similarity of characters associated with phylogenetic relationships between species), thus reflecting the effect of common ancestry (Deanna, Smith, Särkinen \& Chiarini, 2018). Signal loss occurs when some species converge, in relation to a given trait, towards certain environmental conditions. The compartmentalization of processes that lead to the expression of traits reduces dependence 
between them, thus favouring their independent evolution (i.e., closely related species do not tend to resemble each other; Deanna et al., 2018). However, in order to inquire about the evolutionary pattern and specifically about models of chromosome evolution within the subtribes, we need to increase cytogenetic analyses, especially for the Physalidinae subtribe for being the most widely distributed and the one with the greatest morphological diversity (Fig. 1) and specific richness (Zamora Tavares, Martínez, Magallón, Guzmán Dávalos \& Vargas Ponce, 2016).

In the present study we aim to infer evolutionary patterns of chromosome characters onto a molecular phylogeny of the Physalidinae, accounting for an increase of karyological characterization of the genera within this subtribe, especially in the large genus Physalis. Regarding the current knowledge on ploidy level and how informative intrachromosomal and interchromosomal asymmetry have been to distinguish the subtribe lochrominae (Deanna et al., 2018), we aim to characterize chromosomally the Physalidinae. Using comparative statistical methods, we address the following questions: (1) is there an increase of karyotype asymmetry in Physalidinae?, (2) are chromosome patterns informative enough to distinguish clades?, and 3) how many independent changes in the ploidy level have occurred in the group?

\section{Materials and methods}

\subsection{Plant material}

The provenance of the plant material used for cytogenetic studies is presented in Table 1 . Seeds for this study were collected during field trips by F. Chiarini, G. E. Barboza and R. Deanna (Argentina, Colombia, Guatemala, Mexico, Peru and the United States). For each collection of ripe fruits, the location, geographical coordinates and date of collection were documented (Table. 1). Reference specimens were deposited in the herbarium of Museo Botánico de Córdoba (CORD), with duplicates in the herbaria of the province-country of material collection.

\subsection{Classical staining and karyotype analyses}

Seeds were germinated in Petri dishes under controlled photoperiod conditions (16: $8 \mathrm{~h}$ ) and temperature $\left(28 \pm 0.5^{\circ} \mathrm{C}\right)$. To prevent germination failure, they were treated with gibberellic acid $\left(\mathrm{GA}_{3}\right)$ at a concentration of $300 \mathrm{ppm}$ (Ellis, Hong \& Roberts, 1985). Slides with mitotic chromosomes were made from radical apices from germinating seeds treated with 8hydroxyquinoline for $4 \mathrm{~h}$, subsequently fixed in Farmer solution (3: 1 absolute ethyl alcohol and glacial acetic acid) at room temperature for $24 \mathrm{~h}$ and then stored at $4{ }^{\circ} \mathrm{C}$. The fixed roots were digested with a PECTINEX ${ }^{\circledast}$ enzyme solution (60 min at $37^{\circ} \mathrm{C}$ ). Then, a conventional technique was applied for the observation of somatic chromosomes and their morphometric analyses, using Giemsa staining (Sheehan \& Hrapchak, 1980).

At least 10 metaphases per sample were observed and micro-photographed with an Olympus BX61 optical microscope coupled to a monochromatic camera and Cytovision software (Leica Biosystems). Using the software ImageJ (Schneider, Rasband \& Eliceiri, 2012), the following 
characteristics of each chromosome pair were recorded: s (short arm length), I (long arm length), $c$ (total chromosome length) and satellite size. The relationship between the arms ( $r=1$ / s) was used to classify the chromosomes as metacentric ( $r=1$ to 1.7$)$, submetacentric ( $r=1.7$ to 3 ), subtelocentric ( $r=3$ to 7$)$, acrocentric $(r=7$ to 8$)$ and telocentric ( $r=8$ or more) according to the nomenclature of Levan, Fredga \& Sandberg (1964). In addition, the haploid karyotype length $(\mathrm{HKL})$, the mean chromosome length (c), the average of the relationship between arms or brachial index $(r)$, and the ratio between the longest and the smallest chromosome in the complement (R) were calculated for each sample. The terminology of Battaglia (1955) was used to determine if the satellites correspond to microsatellites, macrosatellites or linear satellites. Idiograms based on the average values of each species or population were also made. Karyotype asymmetry was quantified according to Romero Zarco (1986) intrachromosomal $\left(A_{1}\right.$, which accounts for differences between arms of a single chromosome) and interchromosomal $\left(A_{2}\right.$, representing size differences among chromosomes of the same complement) asymmetry indices (Table 2).

\subsection{Chromosome characters database}

A matrix was prepared with the chromosome continuous variables: $c, r, A_{1}$ and $A_{2}$. All the new measurements (except $P$. porrecta), and the species previously analysed by Menzel $(1950,1951$; Table 1) were included. The amount of submetacentric and subtelocentric chromosomes was codified from the karyotype formula. Since these traits have a large number of discrete states, we codified them into three or less states. The amount of subtelocentric chromosomes was codified by establishing three states (' 0 ' in case of absence of pairs, ' 1 ' for species with a single pair and ' 2 ' for species that contain two or more pairs of subtelocentric chromosomes). Similarly, submetacentric chromosomes were also codified in three states (' 0 ' for species containing up to three pairs, ' 1 ' for the ones that present four to six pairs and, finally. ' 2 ' for species containing seven or more pairs).

\subsection{Analysis of chromosome evolution in ChromEvol}

Using the previously published Physalideae phylogeny (Deanna et al., 2019), chromosome number was reconstructed in ChromEvol (Mayrose, Barker \& Otto, 2010; Glick \& Mayrose, 2014), a software which was specifically developed to model the evolution of ploidy. RASP 3.2 program (Yu, Harris, Blair \& He, 2015) was used to make inferences of the ancestral chromosome number in the subtribe, of the location of changes in chromosome number along the phylogeny, and of the total number of changes in the ploidy level of the group, such as it has been carried out in the subtribe lochrominae (Deanna et al., 2018). All the models obtained were tested and compared in their probability values (AIC, Akaike, 1974). We set the base chromosome number as 12 , the rate base number as 1 , the maximal chromosome number as 120 (-10 according RASP settings), and the minimal chromosome number as 12 (1 according RASP settings). The base-number was kept fixed and 10,000 simulations were performed.

\subsection{Ancestral reconstructions of chromosome characters}

The evolution of discrete chromosome features was reconstructed on the maximum clade credibility (MCC) tree using the ace function of the package \{ape\} (Paradis, Claude \& Strimmer, 2004) and the function make.simmap of the package \{phytools\} (Revell, 2012), in R version 3.4 .2 
(R Core Team, 2017). The ancestral states were inferred under a model where all the transition rates are different ("ARD"). Bayesian stochastic mapping (Nielsen, 2001; Huelsenbeck, Nielsen \& Bollback, 2003), was performed with 1,000 simulations on the MCC tree obtained from Deanna et al. (2019). The reconstruction was applied to all species considering the unknown data as ambiguous and inferring the states of these species during reconstruction. We estimated the median number of changes per transition, generally preferred over means for non-normal distributions, and the $95 \%$ credibility interval using the hdr function of the package \{diversitree\} in R (FitzJohn, 2012).

The remaining cytogenetic characters $\left(c, r, A_{1}\right.$ and $\left.A_{2}\right)$, coded as continuous, were mapped and plotted onto the MCC tree, after removing those species without data using the drop.tip function of the package \{ape\} in $\mathrm{R}$ (Paradis et al., 2004). The ancestral states were estimated assuming that the species evolve under a Brownian model and the mapping was performed using the ContMap function of the package \{phytools\} in R version 3.4.2 (Revell, 2012).

\subsection{Phylogenetic signal of continuous traits}

Reconstructions of ancestral states detect whether evolutionary shared stories, according to phylogeny, are the cause of the similarity patterns observed in the data. Therefore, the phylogenetic signal was evaluated based on the set of the continuous characters mentioned before. The statistics $\lambda$ (Pagel, 1999) and K of Blomberg, Garland \& Ives (2003) were inferred using the phylosig function of the package \{phytools\} in R (Revell, 2012). Values of $\lambda$ close to zero correspond to traits that are less similar among species than expected for their phylogenetic relationships, so it follows that there is no phylogenetic signal. Otherwise, values of $\lambda$ close to one correspond to traits that are more similar among closely related species, so it is estimated that there is a phylogenetic signal within the group. Likewise, the highest values of $\mathrm{K}$ indicate a high phylogenetic signal, with a value of one corresponding to the expected covariance under a Brownian evolution model. It was tested if $\mathrm{K}$ is significantly different from one when compared to inferred $\mathrm{K}$ values after 10,000 Brownian trait evolution simulations, implementing the fastBM function of the package \{phytools\} in $R$ (Revell, 2012). We also verify if $K$ is significantly different from zero (without phylogenetic signal) by comparing the estimated values of $K$ with 10,000 null models where the species are randomly mixed using the phylosignal function of the $\{$ spicy\} package in $\mathrm{R}$ (Kembel et al., 2010).

\section{Results}

Karyotype information was recorded for 42 species, including 18 new reports. Chromosome number, ploidy level and karyotype formula were analysed using classical cytogenetic techniques (Table 2, Fig. 1, Suppl. mat. S1).

\subsection{Chromosome numbers and morphology}

Physalidinae has a basic number $X=12$, except Quincula with $X=11$. Most species resulted diploid, except the species of the genus Chamaesaracha, Leucophysalis grandiflora and four species of Physalis, which are polyploid. Most species presented a single pair of chromosomes 
with satellites, except for the tetraploid species that presented two pairs and for Quincula which presented none. The satellites were always located in the short arm of one of the metacentric, submetacentric or subtelocentric pairs (Fig. 2; Suppl. mat. S1). Among the studied species that presented satellite, only five presented microsatellites and 10 presented macrosatellite. No species were observed with linear satellites (Suppl. mat. S1).

The species studied here were heterogeneous concerning chromosome size, with total average chromosome length (c) between 1.62-4.20 $\mu \mathrm{m}$ (Table 2), although the highest c reported was Calliphysalis carpenteri with $4.85 \mu \mathrm{m}$ (Menzel, 1951; Suppl. mat. S2). The smallest c was found in $P$. victoriana $(1.62 \mu \mathrm{m})$ and the largest in $P$. cinerascens var. spathulifolia $(4.20 \mu \mathrm{m})$. Accordingly, the largest absolute chromosome length was found in $P$. cinerascens var. spathulifolia $(5.72 \mu \mathrm{m})$ and the smallest in P. peruviana $(1.08 \mu \mathrm{m})$. Among the species analysed, HKL had a 3.11-fold variation (from $19.39 \mu \mathrm{m}$ in the diploid $P$. victoriana to $60.27 \mu \mathrm{m}$ in the polyploid $P$. pubescens).

The karyotypes of the Physalidinae studied are remarkably asymmetric, composed of metacentric, submetacentric and subtelocentric chromosomes, with the exception of $P$. philadelphica that only has metacentric and submetacentric chromosomes (Table 1, Fig. 2). Furthermore, notable differences were found among the species studied here in intrachromosomal asymmetry ( $A_{1}$ varied from 0.28 to 0.59 ; Suppl. mat. S3) and also along the chromosome size of the same complement ( $A_{2}$ from 0.11 to 0.21 ; Suppl. mat. S4). On average, arm ratio $(r)$ was 2.12 (range $=1.46-2.77$; Table 2; Suppl. mat. S5).

Through the integrative analyses of $A_{1} v s A_{2}$, we resolved that most species are grouped into two large groups. On the one hand, we have the most symmetrical genera such as all the belonging to lochrominae subtribe (e.g., lochroma Benth., Saracha Ruiz \& Pav.), Witheringia L'Hér. and Schraderanthus Averett. On the other hand, we find Physalis, Chamaesaracha and Quincula grouped for being the most asymmetric genera in the tribe (Fig. 3). The complements of the clade Physalis + Quincula + Chamaesaracha (PQC, from now on) are markedly more asymmetric than those of the other genera of the subtribe Physalidinae (Fig. 3, Suppl. mat. S4-S5), presenting: 1 to 8 m chromosomes $(\bar{x}=5) ; 1$ to 9 sm chromosomes $(\bar{x}=4) ; 1$ to 5 st chromosomes $(\bar{x}=2) ; t=1$ pair in two species (Table 2, Fig. 2, Suppl. mat. S1).

\subsection{Ancestral states reconstruction}

As a result of the chromosome number reconstructions using ChromEvol, the 'CONST_RATE' model $(A I C=65.52)$ was selected as the best-fitting model for the dataset. Reconstructions supported diploidy $(2 n=24)$ as the ancestral state for the Physalidinae subtribe, and five to six polyploidy events were estimated, plus one aneuploidy event in the monotypic genus Quincula (Fig. 4).

Continuous characters mapped on the MCC tree are represented with phenograms (Fig. 5). The arm ratio ( $r$ ) clearly differs among clades, with an estimated value around 1.96 for the ancestor of all Physalidinae (Fig. 5.3, Suppl. mat. S5). Accordingly, both asymmetry indices showed strong phylogenetic patterns among different clades (Figs. 5.1 and 5.2, Table 4). 
Regarding the Bayesian stochastic mapping for number of submetacentric and subtelocentric chromosomes, both reconstructions resulted in a similar number of changes ( 23 total shifts in submetacentric chromosome states and 22 total changes for the subtelocentric chromosomes; Table 3). They showed similarities in the number of gains; six gains of four or more pairs of submetacentric chromosomes, and 15 gains of two or more pairs of subtelocentric chromosomes (Table 3; Fig. 6; Suppl. mat. S6).

\subsection{Phylogenetic signal}

Regarding chromosome size (c), the Blomberg's K was not significantly different from zero (Table 4). For the remaining traits analysed (relationship between arms and intra- and interchromosomal asymmetry), Blomberg's K was significantly different from zero, but not significantly different from one, indicating a phylogenetic signal in the asymmetry pattern (Table 4). Between both asymmetry indices, the strongest phylogenetic signal was found in the intrachromosomal asymmetry index $\left(\mathrm{A}_{1}\right.$, Table 4$)$.

\section{Discussion}

Chromosome number. Solanaceae shows a dysploid series from $x=7$ to $x=14$ (cf. Goldblatt \& Johnson, 1979 onwards; Rice et al., 2015). A hypothesis on chromosome number changes is still lacking, and even the original basic number for the family is a matter to be clarified. Based on phylogenetic studies, Olmstead et al. (2008) suggested that $x=12$ is apomorphic. This is the most frequent base number and characterizes an entire clade, the so-called $x=12$ clade, in which Physalideae is placed. Within the $x=12$ clade, evidence for dysploid changes to $x=13$ via translocations has been reported in Capsicum L. (Moscone et al., 2006) and Solanum L. (subg. Lycopersicon; Banks, 1984). However, such type of chromosome change is rare; most species with a chromosome number different from $\mathrm{x}=12$ belong to Capsicum, whereas in Solanum dysploidy (with $\mathrm{x}=23$ ) seems to be a synapomorphy of a few species (Chiarini, Sazatornil \& Bernardello, 2018). Quincula lobata has both diploid and tetraploid races of the basic number 11 , with at least occasional aneuploid individuals ( $2 n=20$, Menzel, 1950). Thus, the number $x=$ 11 found in Quincula is peculiar, being the Robertsonian translocation the most likely explanation for its origin. Following such a scheme, two telocentric chromosomes would have exchanged their arms, giving as result a big metacentric chromosome and a tiny one formed by the two short arms, which is subsequently lost. An alternative explanation would be the fusion of two telocentric by their short arms with a later inactivation of one centromere. Both explanations are plausible considering that the presence of several pairs of telocentric chromosomes is one of the outstanding features found in the Physalidinae karyotypes.

Except for Quincula, the basic number X = 12 is constant in all Physalidinae as far as we know, although the occurrence of several independent events of polyploidy within the group was verified. This can be related to processes of speciation and colonization of new habitats. The role of genome duplications during the invasion of new habitats has been the subject of intense debate (Stebbins, 1985; Soltis et al. 2004). Polyploids frequently have a wider geographical range than their diploid parents (e.g., Schönswetter et al., 2007; Whittemore \& Olsen, 2011), probably 
because they are preadapted to habitats and resources off limits to their parents (Levin, 2003). They have a diversity of alleles that can confer a greater ecological niche than that of diploid progenitors (Brown, 1984; Pound et al., 2004). To this respect, we found two situations in Physalidinae: on the one hand, the genus Chamaesaracha, where polyploidy might be related to the colonization of the deserts of Northern Mexico and South Western USA, beyond a hypothetical wetter range of origin. According to Zamora Tavares et al. (2016), the diversification of Physalis took place mainly in the Mexican Transition Zone 6.5 mya, when the formation of mountain ranges in this region generated altitudinal and climatic changes that led to the diversification and radiation of taxa. The ancestral distribution for Chamaesaracha is the Nearctic and it is characterized by their adaptation to xeric conditions and present more recent divergence dates (5.81-1.59 mya) that coincide with the aridification of North America during the Pliocene (Zamora Tavares et al., 2016). On the other hand, we also found polyploidy in some Physalis, which are precisely the species with a wide distribution, probably related to anthropic dispersion. As polyploids often exhibit increased vigour and, sometimes, outmatch their diploid relatives in several aspects, this superiority has been targeted by humans, who have induced polyploidy or have selected natural polyploids in order to obtain improved cultivars (Sattler, Carvalho \& Clarindo, 2016). This would be the case of $P$. angulata and $P$. pubescens (growing from USA to Argentina and introduced in the Old World; Yamazaki, 1993; Toledo \& Barboza, 2013) and P. peruviana (native from Peru but introduced also in the Old World; Brako \& Zarucchi, 1993; Zhang et al., 1994).

Chromosome size. Chromosome length is useful to single out individuals, samples, populations or species, besides being an indirect indicator of the total DNA amount. Solanaceae show notable variation in chromosome size, with an 8-9-fold range (Badr et al., 1997; Chiarini et al., 2018). Most species have small or medium-sized chromosomes with respect to other angiosperms (Levin \& Funderburg, 1979; Weiss Schneeweiss \& Schneeweiss, 2013), mostly within the 1-3 $\mu \mathrm{m}$ range. Our records on Physalis fit in this pattern and confirm previous data (Menzel, 1950, 1951; Rodriguez \& Bueno, 2006). We found a 1-fold size variation, similar to the measurements reported by Menzel $(1950,1951)$, which is still considered a slight variation compared to the sizes found in the family.

Stebbins (1971) proposed a relationship between habit and chromosome size, with perennial species having small chromosomes. Species of subtribe Physalidinae are mostly herbs, whereas its sister clade, lochrominae, is characterized by the woody habit. However, no marked differences in chromosome size were found when comparing both clades. Also in other woody genera of the family, chromosomes are either small (e.g., Lycium L., Stiefkens \& Bernardello, 2000; Lycianthes (Dunal) Hassl., Acosta, Bernardello, Guerra \& Moscone, 2005), or medium-sized (Latua pubiflora (Griseb.) Baill., Chiarini et al., 2010).

Genome downsizing is a phenomenon that apparently occurs in polyploids (Leitch \& Bennett, 2004). Theoretically, polyploids are expected to have larger DNA content than their diploid progenitors, increasing in direct proportion with ploidy, but this is true mostly in newly formed polyploid series. Contrarily, there are cases in which, either the mean 1C DNA amount does not increase proportionally with ploidy, or the mean DNA amount per basic genome ( $2 \mathrm{C}$ value divided by ploidy) tend to decrease with increasing ploidy (Leitch \& Bennett, 2004). Gene 
reordering and deletion of redundant material have been proposed to account for this DNA content decrease, and these changes may be reflected on chromosome length, considering that length is an indirect indicator of the total DNA amount. Also, polyploids may have proportionally less DNA amount but yet share the same chromosome morphology with their diploid relatives. For instance, Poggio, Realini, Fourastié, García \& González (2014) found that in Hippeastrum (Amarillydaceae), polyploid species show less DNA content per basic genome than diploid species, but the typical bimodal karyotype is preserved, even in the presence of genome downsizing. The authors suggest that constancy of the karyotype is maintained because changes in DNA amount are proportional to the length of the whole chromosome complement and vary independently in the long and short sets of chromosomes. In the accessions here studied, we found also a constancy: despite they can vary on c, species of the PQC clade have similar formulae, which in average would be $5 m+4 s m+2 s t+1 t$. Even polyploids have formulae which are the double of this average formula, however their chromosomes are slightly smaller compared to the diploid species.

Karyotype asymmetry. Within the $x=12$ clade there are some genera that present a high constancy in chromosome morphology, with symmetrical karyotypes and a majority of $m$ chromosomes of rather similar size, e.g., Lycium (Stiefkens \& Bernardello, 2000), but at the same time, complements that include st and t chromosomes are found in species of Nicotiana, Capsicum, Jaborosa, in some Solanum (Acosta et al., 2005; Chiarini \& Barboza, 2008; Menzel, 1951) and in Physalis (Menzel, 1951; Venkateswarlu \& Raja Rao, 1977, 1979a, 1979b; Rodríguez \& Bueno, 2006). Karyotypes that are highly symmetrical have been considered primitive (Stebbins, 1971), but concurrently, a karyotype orthoselection has been hypothesized for the conservation of complements with homogeneous chromosomes (Brandham \& Doherty, 1998; Moscone et al., 2003). It is difficult to establish the direction of karyotype evolution, as many reversals might have occurred (Stace, 2000), and karyotype asymmetry might be a transient state rather than a derived evolutionary end (Mandakova \& Lysak, 2008). However, our reconstructions of chromosomal characters indicate that the most probable character state for the ancestor of all Physalideae and Physalidinae had a formula with none st chromosomes. The probability of having a karyotype with at least one st becomes higher with the common ancestor of the clade PQC, and this trend increases in some species groups within Physalis which present formulae with more than two st chromosomes. Thus, the karyotype changes in Physalideae would be directional towards an asymmetric karyotype in the PQC clade.

Transitions between karyotype formulae can be interpreted as evidence of chromosome rearrangements. Specifically, formulae with st or t chromosomes are seemingly the result of a deletion or translocation of the entire or part of one arm (Weiss Schneeweiss \& Schneeweiss, 2013). Species of the PQC clade share markedly asymmetrical formulae $(5 m+4 s m+2 s t+1 s t$ or $6 m+4 s m+2 s t)$. Witheringia is symmetrical ( $9 m+3 s m$, Barboza et al., 2010; Chiarini et al., 2010) and the rest of genera in the tribe Physalideae are so (Athenaea Sendtn. And Deprea Raf., 9m + 3sm; Deanna et al., 2014; Chiarini et al., 2017), whereas subtribe lochrominae is even more symmetrical $(11 \mathrm{~m}+1 \mathrm{sm}$ or $12 \mathrm{~m}$, Deanna et al., 2018). The most parsimonious explanation for this situation is that large chromosome rearrangements would have occurred when the common ancestor for PQC separated from the ancestor that gave rise to the clade formed by Calliphysalis 
+ Alkekengi + Oryctes, this latter retaining a symmetrical karyotype. This is another argument that supports the segregation of these three genera outside of Physalis, where they were previously assigned (Pretz \& Deanna, 2020).

According to our ASR, symmetrical karyotypes are plesiomorphic, being asymmetry a synapomorphy of the PQC clade, while Calliphysalis + Alkekengi + Oryctes would have conserved symmetry. This supports the idea that shifts in chromosome morphology are quite common when considering wide frames of time. The papers of Wu \& Tanskley (2010) and Chiarini et al. (2018) provided estimates of such frequency by dividing evolutionary time by number of chromosome rearrangements (what yields one rearrangement per complement approximately every $2.93 \mathrm{my}$, or 0.34 rearrangement per million years). This supports the idea that diversification in the PQC clade has been recent, and not enough time has passed for so many rearrangements to accumulate and blur this uniform pattern of asymmetric karyotypes. Even though, chromosome traits are informative to distinguish clades: from the traitgrams of Fig. 5 is clear that the $A_{1}$ index has a strong phylogenetic signal, separating lochrominae from the PQC clade. This congruence between karyotypes evolution and the splits and differentiation of clades within phylogenies has already noticed in genera from different plant families (e.g., Blöch et al., 2009; Baltisberger \& Hörandl, 2016). It is unlikely that extant species with divergent karyotypes are able to cross, whereas species with the same karyotype should be capable of producing hybrids.

Taxonomic implications. Our results provide evidence on the following taxonomic issues: 1) Support to differentiate the genus Quincula from Physalis and Chamaesaracha, on the grounds of its exclusive basic number and particular morphology (Barboza, 2000); 2) Maintenance of $P$. solanacea within Physalis instead of placing it in a monotypic genus (as Margaranthus solanaceus Schltdl.), based on similarities in formulae and asymmetry indices as well as phylogenetic placement (Whitson \& Manos, 2005; Zamora-Tavares et al., 2016; Deanna et al., 2019); 3) Segregation of Calliphysalis Whitson and Alkekengi Mill. out of Physalis, on the basis of their symmetrical karyotypes, morphological features and phylogenetic placement (cfr. Pretz \& Deanna, 2020); and 4) Support to distinguish Deprea from Physalis: some species of Deprea have inflated fruiting calyx which has confused them to be mistaken by Physalis, but both genera can be easily distinguished by their karyotypes, as well as phylogenetic distance and floral traits (Whitson \& Manos, 2005; Deanna et al., 2019).

However, to complete the chromosome evolution picture within Physalideae and confirm that asymmetry is a characteristic of only the PQC clade, more karyotype studies are needed in the remaining clades of the tribe (especially those fromAsia, like Physaliastrum Makino; Zhang et al., 1994). Chromosome number and morphology are still unknown for the genera Mellissia Hook.f., Cuatresia Hunz., Brachistus Miers and also for the genera recently segregated from Physalis: Tzeltalia E.Estrada \& M.Martínez, Archiphysalis Kuang, and Darcyanthus Hunz. ex N.A.Harriman (Pretz \& Deanna, 2020).

Conclusions In accordance with our results on ASR, the common ancestor to all the subtribe Physalidinae was a diploid with $2 n=24$, with a karyotype with up to three sm chromosomes, an arm ratio of ca. 1.96 , and approximately $A_{1}=0.35$ and $A_{2}=0.14$. Polyploidy occurred six times 
after the divergence of Physalidinae from the rest of the Physalideae, and one aneuploidy event was involved in the split of Quincula. These numeric alterations can be related to processes of speciation and colonization of new habitats. The main evolutionary trends with respect to the ancestor were: an increase of asymmetry in the lineage that originated the PQC clade; a decrease of asymmetry in lochrominae and Witheringia. Both asymmetry indices allow to differentiate genera within the subtribe. Overall, our study suggests that Physalideae diversification has been accompanied by karyotype changes, which can be applied in the delimitation of genera within the group.

The results here analysed raise questions for future prospects: 1) Is there a relationship among karyotype formulae and different macromorphological and ecological features, as habit, niche or life form? Such relationships are usually hypothesized but not tested. For example, Menzel (1950) proposed a correlation among ploidy, seed size, and geographic range, suggesting that individuals with larger seeds would have higher ploidy, but this matter remains inconclusive. 2) Concerning traits of agronomic value, do the polyploid Physalidinae outmatch in size, vigour or even environmental resilience their diploid parents? The most important crops worldwide are polyploids (Sattler et al., 2016) so it would be useful to address this question for the ongoing improvement programs on ground cherries and golden berries (Physalis).

\section{Acknowledgements}

The authors thank the National Council for Scientific Research and Techniques (CONICET), National Agency for Scientific Promotion and Technological (FONCYT, grant \# PICT 2017-2370 and 2016-1525) and SECYT (National University of Córdoba, Argentina, grant \# 203/14) for financial support, equipment and facilities. We thank Chelsea Pretz, Tiina Sarkinen, Sandra Knapp from http://solanaceaesource.org/, and G. Chaniot from https://www.inaturalist.org/ for their contribution in photographic material. 


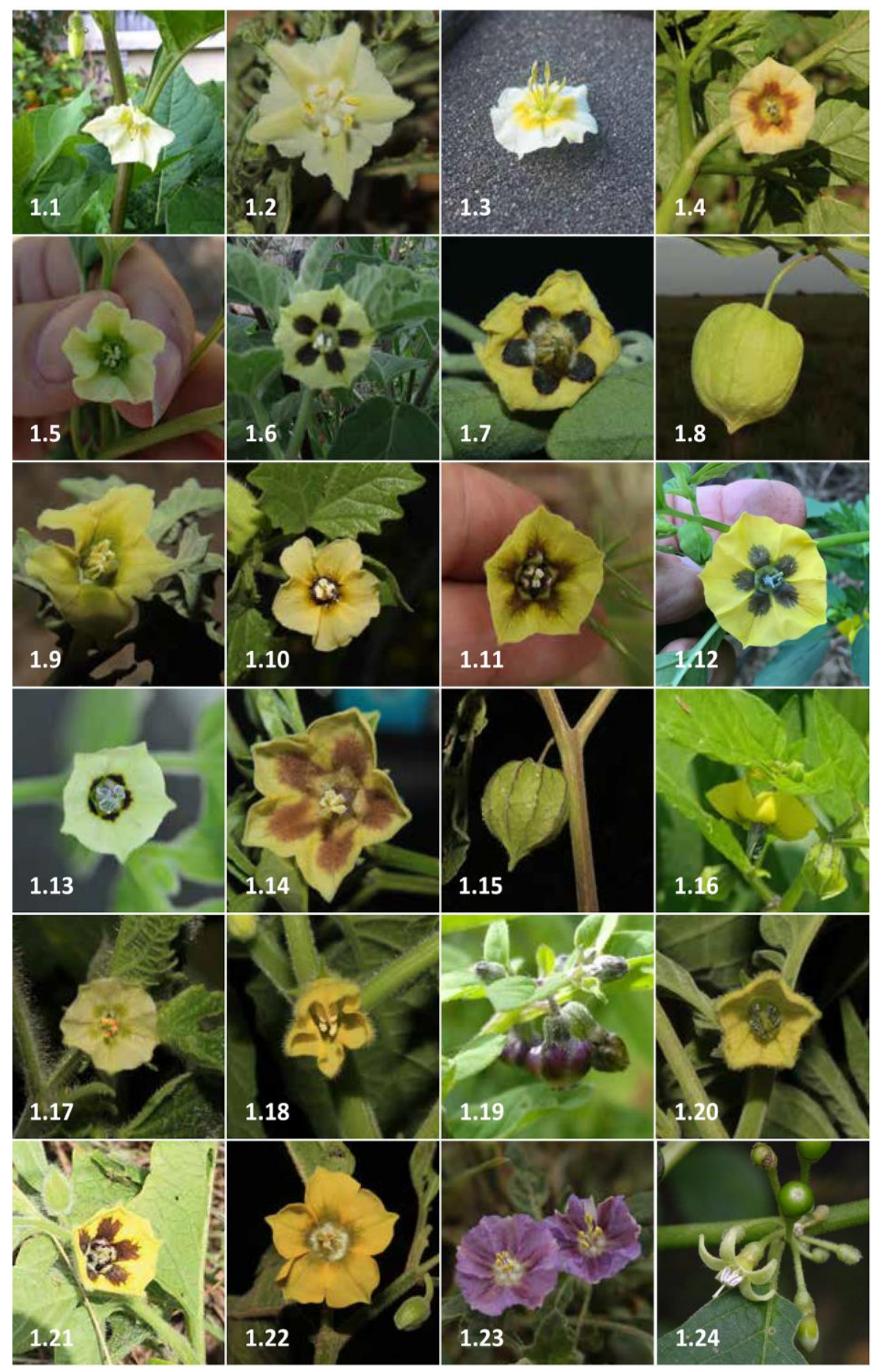

Fig. 1. Species of Physalidinae currently cytogenetically analysed. (1.1) Alkekengi officinarum var. officinarum, flower (1.2) C. coronopus, fower (1.3) P. acutifolia, flower (1.4) P. angulata, flower (1.5) P. crassifolia, flower (1.6) P. chenopodifolia, flower (1.7) P. cinerascens var. cinerascens, flower (1.8) $P$. cinerascens var. spathulifolia, fruit (1.9) $P$. fendleri, flower (1.10) $P$. hederifolia, flower (1.11) $P$. heterophylla, flower (1.12) P. ixocarpa, flower (1.13) P. lagascae, flower (1.14) P. longifolia, flower (1.15) P. peruviana, fruit (1.16) P. philadelphica, flower (1.17) P. pruinosa, flower (1.18) P. pubescens, flower (1.19) $P$. solanaceae, mature fruits (1.20) P. victoriana, flower (1.21) P. virginiana, flower (1.22) $P$. viscosa, flower (1.23) Q. lobata, flower (1.24) W. solanacea, flower. Photographs by C. Pretz $(3,5,16,19)$; G. Chaniot (12); R. Deanna (2, 4, 6, 7, 8, 9, 10, 11, 14, 15, 17, 18, 20, 21, 22, 23, 24); S. Knapp (1); T. Sarkinen (13). 

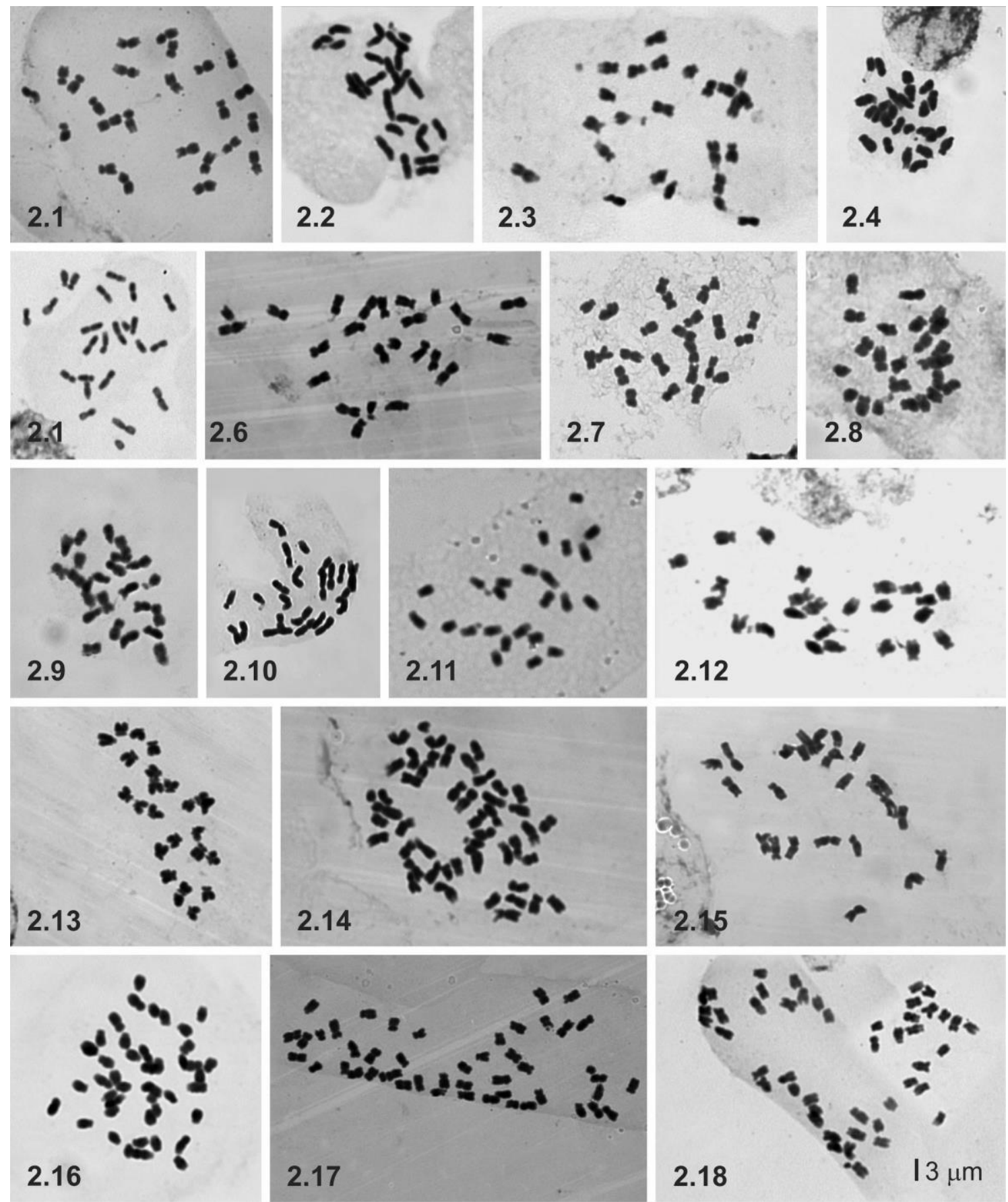

Fig. 2. Somatic metaphases of Physalidineae with Giemsa staining. (2.1) Alkekengi officinarum. (2.2) P. hederifolia. (2.3) P. ixocarpa. (2.4) P. porrecta. (2.5) P. cinerascens var. spathulifolia. (2.6) P. chenopodifolia. (2.7) P. cinerascens var. cinerascens. (2.8) P. philadelphica. (2.9) P. fendleri. (2.10) P. longifolia. (2.11) P. victoriana. (2.12) P. virginiana. (2.13) P. lagascae. (2.14) P. pubescens. (2.15) P. viscosa. (2.16) Quincula lobata. (2.17) P. peruviana. (2.18) Chamaesaracha coronopus. All the pictures at the same scale. 


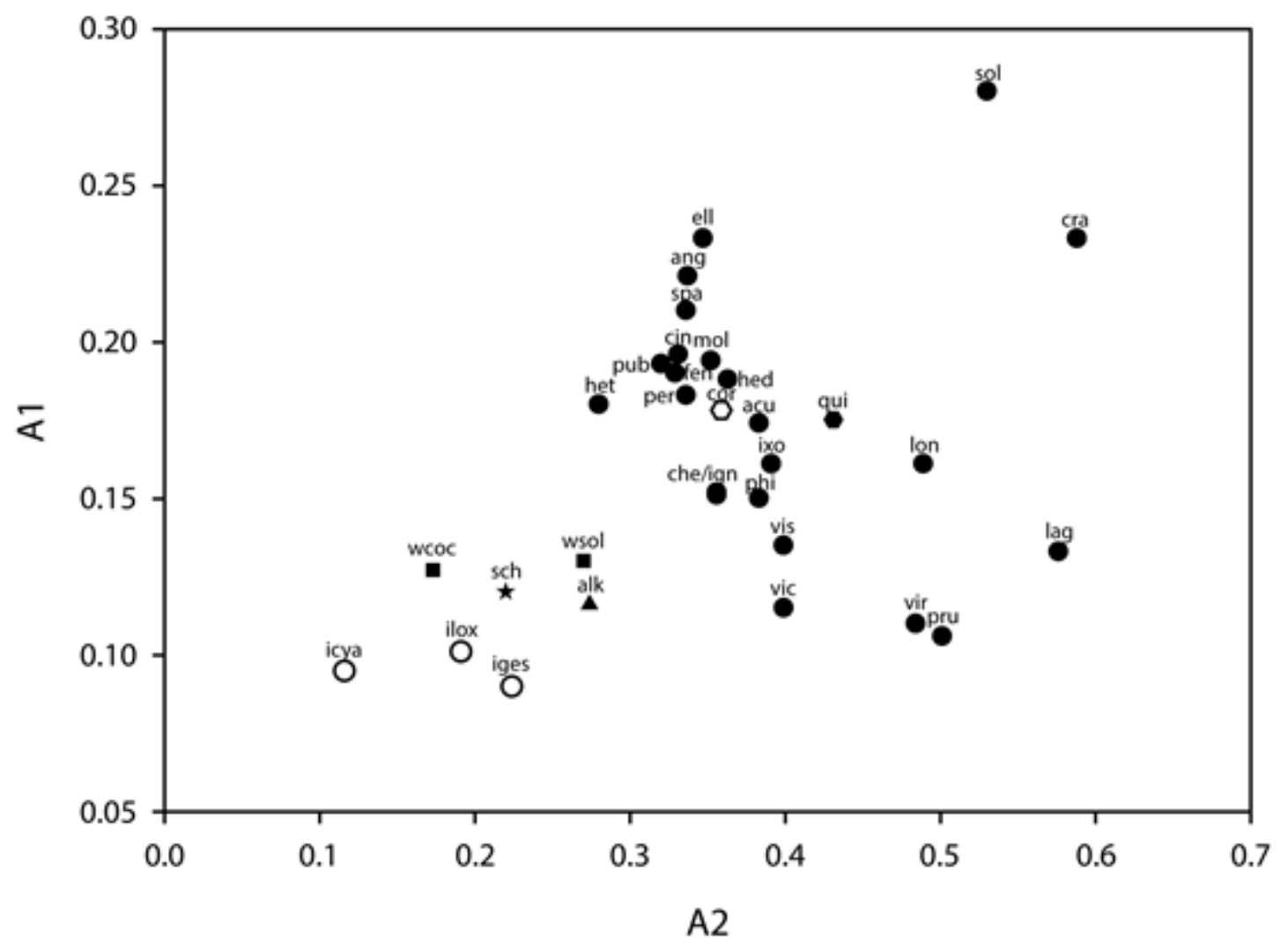

Fig. 3. Diagram showing the intrachromosomal asymmetry index $\left(A_{1}\right)$ plotted against the interchromosomal asymmetry index $\left(A_{2}\right)$. Species codes are given in table 1 . The genera were represented with the following shapes. Solid circles $(\bullet)$ for Physalis, empty circles $(O)$ for lochroma, solid triangles ( $\mathbf{\Delta})$ for Alkekengi, solid hexagons ( $\bullet$ ) for Quincula, empty hexagons (0) for Chamaesaracha, solid squares ( $₫$ ) for Witheringia and a star ( $\star$ ) for Schraderanthus. 


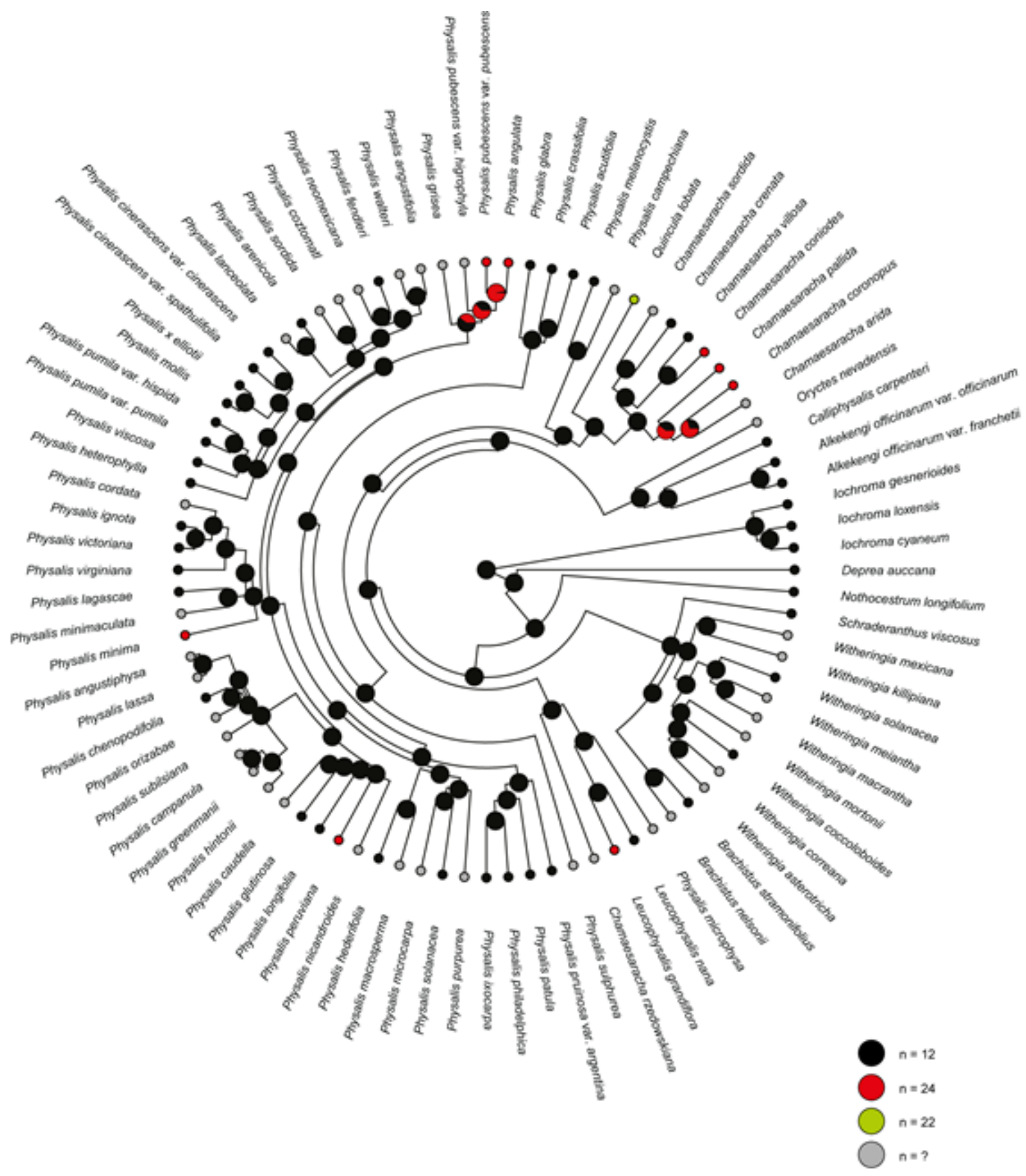

Fig. 4. Chromosome haploid number (n) reconstruction in the Physalidinae subtribe with ChromEvol in RASP. Pies at nodes represent frequencies of node states across 10000 simulations of character evolution. Grey pies at tips represent unknown data. 


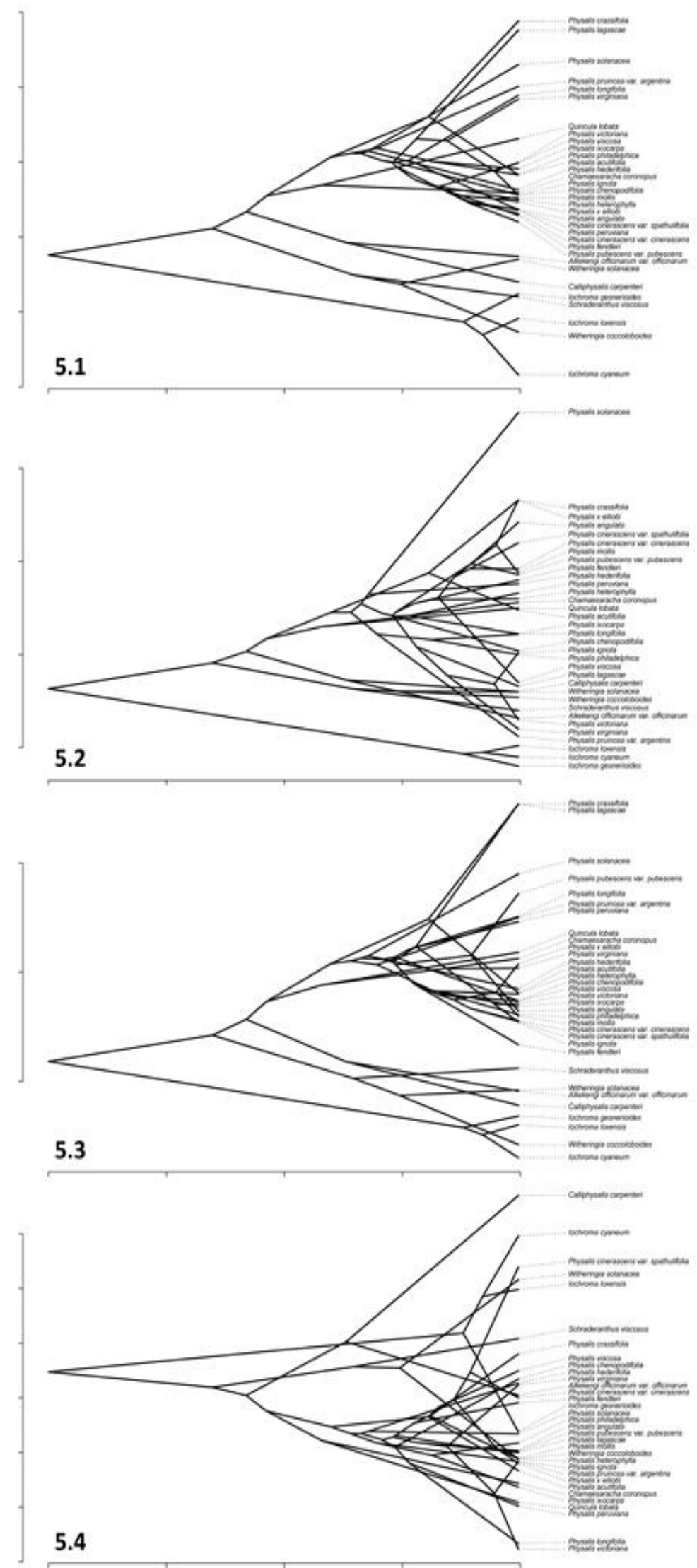

Fig. 5. Traitgrams for continuous traits analysed. (5.1) Intrachromosomal asymmetry index $\left(A_{1}\right)$; (5.2) Interchromosomal asymmetry index $\left(A_{2}\right),(5.3)$ Mean arm ratio ( $r$ ); and (5.4) Total average chromosome length (c). 


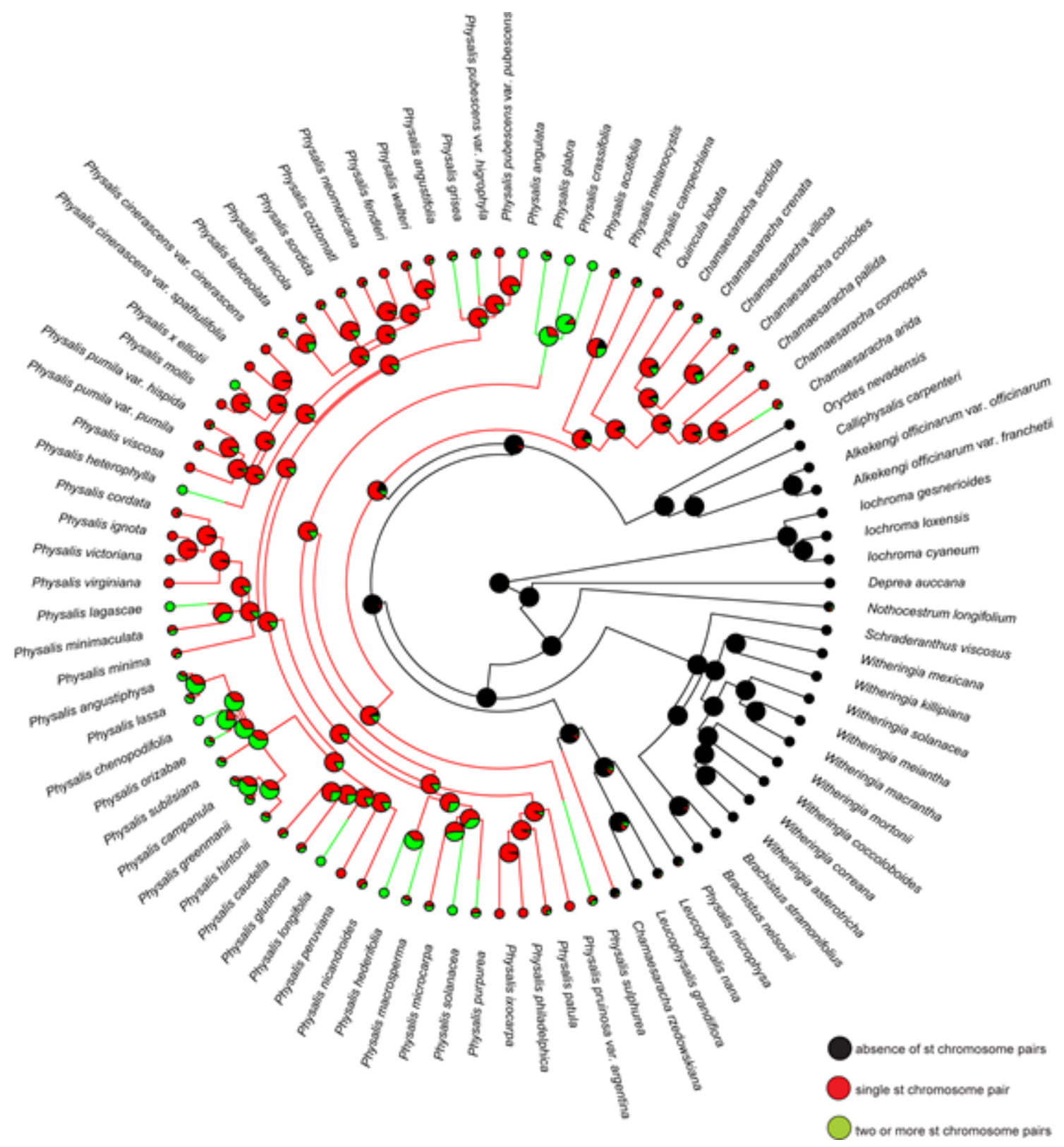

Fig. 6. Ancestral state reconstruction of the number of subtelocentric (st) chromosome pairs in the Physalidinae subtribe on the combined MCC tree, using stochastic mapping. Pies at nodes indicate frequencies of node states across 1000 simulations of character evolution and the colours of the tip labels represent tip states. 
Table 1. List of samples studied, code, provenance and reference (only if the species was previously studied) of all the analysed species of Alkekengi, Chamaesaracha, lochroma, Physalis, Quincula and Witheringia.

\begin{tabular}{|c|c|c|c|c|}
\hline Species & Code & Voucher & Provenance & Reference \\
\hline $\begin{array}{l}\text { Alkekengi officinarum } \\
\text { Moench }\end{array}$ & alk & $\begin{array}{l}\text { Deanna \& Wei } \\
429 \text { (CORD) }\end{array}$ & $\begin{array}{l}\text { CHINA. Pekin, Beijing city, cultivated at } \\
\text { Botanical Garden of National Academy } \\
\text { of Sciences, Institute of Botany, } \\
\text { Medicinal Plants Area, } 26 / 07 / 2019 \text {. }\end{array}$ & this article \\
\hline $\begin{array}{l}\text { Chamaesaracha } \\
\text { coronopus (Dunal) } \\
\text { A.Gray }\end{array}$ & cor & $\begin{array}{l}\text { Deanna \& } \\
\text { Carrasco } 237 \\
\text { (COLO, CORD) }\end{array}$ & $\begin{array}{l}\text { UNITED STATES. Colorado, Pueblo Co., } \\
\text { Lake Pueblo State Park. }\end{array}$ & this article \\
\hline $\begin{array}{l}\text { lochroma cyaneum } \\
\text { (Lindl.) M.L.Green }\end{array}$ & icya & Smith 265 (WIS) & $\begin{array}{l}\text { UNITED STATES. Grown from seed at } \\
\text { UW-Madison. Original collection by W.G. } \\
\text { D'Arcy, grown at Missouri Botanical } \\
\text { Gardens }\end{array}$ & this article \\
\hline $\begin{array}{l}\text { lochroma } \\
\text { gesnerioides (Kunth) } \\
\text { Miers }\end{array}$ & iges & Smith 266 (WIS) & $\begin{array}{l}\text { UNITED STATES. Grown from seed at } \\
\text { UW-Madison. Origin, Leipzig Bot. } \\
\text { Garden, Nijmegen accession } 934750129\end{array}$ & $\begin{array}{l}\text { Deanna et al., } \\
2018\end{array}$ \\
\hline $\begin{array}{l}\text { lochroma loxense } \\
\text { Miers }\end{array}$ & ilox & $\begin{array}{l}\text { Smith } 220 \text { (WIS, } \\
\text { MO) }\end{array}$ & ECUADOR. Loja. & $\begin{array}{l}\text { Deanna et al., } \\
2018\end{array}$ \\
\hline $\begin{array}{l}\text { Physalis acutifolia } \\
\text { (Miers) Sandwith [as } \\
\text { P. wrighti Gray] }\end{array}$ & acu & $\begin{array}{l}\text { Gould } 3938 \\
\text { (accession 554a) }\end{array}$ & UNITED STATES. Arizona, Tucson. & Menzel, 1951 \\
\hline Physalis angulata $\mathrm{L}$. & ang & $\begin{array}{l}\text { Langford s.n. } \\
\text { (accession 521a) }\end{array}$ & PERU. Tinga Maria. & Menzel, 1951 \\
\hline $\begin{array}{l}\text { Physalis crassifolia } \\
\text { Benth. }\end{array}$ & cra & $\begin{array}{l}\text { Gould \& Darrow } \\
4322 \text { (accession } \\
551 a \text { ) }\end{array}$ & $\begin{array}{l}\text { UNITED STATES. Arizona, Mohave Co., } \\
\text { north of Signal. }\end{array}$ & Menzel, 1951 \\
\hline $\begin{array}{l}\text { Physalis } \\
\text { chenopodiifolia Lam. }\end{array}$ & che & $\begin{array}{l}\text { Chiarini } 1277 \\
\text { (CORD) }\end{array}$ & $\begin{array}{l}\text { MEXICO. Estado de México, Pirámides } \\
\text { de Teotihuacan. }\end{array}$ & $\begin{array}{l}\text { Deanna et al., } \\
2018\end{array}$ \\
\hline $\begin{array}{l}\text { Physalis cinerascens } \\
\text { var. cinerascens } \\
\text { (Dunal) Hitchc }\end{array}$ & $\operatorname{cin}$ & $\begin{array}{l}\text { Deanna, Pretz \& } \\
\text { Carrasco } 206 \\
\text { (COLO, CORD) }\end{array}$ & $\begin{array}{l}\text { UNITED STATES. Texas, Comal Co., } \\
\text { Schmucks and Doeppensmidt roadsides. }\end{array}$ & this article \\
\hline $\begin{array}{l}\text { Physalis cinerascens } \\
\text { var. spathulifolia } \\
\text { (Torr.) J.R.Sullivan }\end{array}$ & spa & $\begin{array}{l}\text { Deanna, Pretz \& } \\
\text { Carrasco } 203 \\
\text { (COLO, CORD) }\end{array}$ & $\begin{array}{l}\text { UNITED STATES. Texas, Colorado Co., } \\
\text { East to the Attwater Prairie Chicken } \\
\text { National Wildlife Refuge. }\end{array}$ & this article \\
\hline $\begin{array}{l}\text { Physalis } \times \text { elliottii } \\
\text { Kunze }\end{array}$ & ell & $\begin{array}{l}\text { Gregory s.n. } \\
\text { (accession 397a) }\end{array}$ & UNITED STATES. Florida, Punta Gorda. & Menzel, 1951 \\
\hline $\begin{array}{l}\text { Physalis fendleri } \\
\text { A.Gray }\end{array}$ & fen & $\begin{array}{l}\text { Deanna, Pretz \& } \\
\text { Carrasco } 219 \\
\text { (COLO, CORD) }\end{array}$ & $\begin{array}{l}\text { UNITED STATES. New Mexico, Grant Co., } \\
\text { outside of Silver City, along Ridge Road. }\end{array}$ & this article \\
\hline $\begin{array}{l}\text { Physalis hederifolia } \\
\text { A.Gray }\end{array}$ & hed & $\begin{array}{l}\text { Deanna, Pretz \& } \\
\text { Carrasco } 209\end{array}$ & $\begin{array}{l}\text { UNITED STATES. Texas, Uvalde Co., along } \\
\text { S side of an E-W stretch of Dry Frio River. }\end{array}$ & this article \\
\hline
\end{tabular}




\begin{tabular}{|c|c|c|c|c|}
\hline & & (COLO, CORD) & & \\
\hline $\begin{array}{l}\text { Physalis heterophylla } \\
\text { Nees }\end{array}$ & het & $\begin{array}{l}\text { Gentry s.n. } \\
\text { (accession 528a) }\end{array}$ & $\begin{array}{l}\text { UNITED STATES. Michigan, Arnold } \\
\text { Arboretum. }\end{array}$ & Menzel, 1951 \\
\hline $\begin{array}{l}\text { Physalis ignota } \\
\text { Britton }\end{array}$ & ign & $\begin{array}{l}\text { Atchinson s.n. } \\
\text { (accession 530a) }\end{array}$ & CUBA. Cienfuegos. & Menzel, 1951 \\
\hline $\begin{array}{l}\text { Physalis ixocarpa } \\
\text { Brot. Ex Hornem. }\end{array}$ & Ixo & $\begin{array}{l}\text { Deanna } 251 \\
\text { (CORD) }\end{array}$ & $\begin{array}{l}\text { UNITED STATES. Colorado, County } \\
\text { Boulder, Ramaley. }\end{array}$ & This article \\
\hline $\begin{array}{l}\text { Physalis lagascae } \\
\text { Roem. \& Schult. }\end{array}$ & Lag & $\begin{array}{l}\text { Sarkinen } 4548 \\
\text { (CORD, E) }\end{array}$ & $\begin{array}{l}\text { UNITED STATES. Utah, Salt Lake City, Red } \\
\text { Butte Botanical Garden. }\end{array}$ & This article \\
\hline $\begin{array}{l}\text { Physalis longifolia } \\
\text { Nutt. }\end{array}$ & Lon & $\begin{array}{l}\text { Gilmer \& Bohs } \\
4087 \text { (UT) }\end{array}$ & $\begin{array}{l}\text { UNITED STATES. Utah, Salt Lake City, Red } \\
\text { Butte Botanical Garden. }\end{array}$ & This article \\
\hline Physalis mollis Nutt. & Mol & $\begin{array}{l}\text { Holt s.n. } \\
\text { (accession 416a) }\end{array}$ & UNITED STATES. Texas, Camp Barkeley. & Menzel, 1951 \\
\hline Physalis peruviana $\mathrm{L}$. & per & $\begin{array}{l}\text { Deanna } 178 \\
\text { (CORD) }\end{array}$ & $\begin{array}{l}\text { Cultivated, seeds from commercial } \\
\text { source }\end{array}$ & $\begin{array}{l}\text { Deanna et al., } \\
2018\end{array}$ \\
\hline $\begin{array}{l}\text { Physalis philadelphica } \\
\text { Lam. }\end{array}$ & phi & $\begin{array}{l}\text { Chiarini } 1437 \\
\text { (CORD) }\end{array}$ & $\begin{array}{l}\text { UNITED STATES. Utah, Salt Lake City, Red } \\
\text { Butte Botanical Garden. }\end{array}$ & this article \\
\hline $\begin{array}{l}\text { Physalis pruinosa var. } \\
\text { argentina J.M.Toledo } \\
\text { \& Barboza }\end{array}$ & pru & $\begin{array}{l}\text { Atchinson s.n. } \\
\text { (accession 531a) }\end{array}$ & $\begin{array}{l}\text { UNITED STATES. Cultivated, Earl May } \\
\text { Seed Co. }\end{array}$ & Menzel, 1951 \\
\hline $\begin{array}{l}\text { Physalis porrecta } \\
\text { Waterf. }\end{array}$ & por & $\begin{array}{l}\text { Deanna } 410 \\
\text { (CORD) }\end{array}$ & $\begin{array}{l}\text { GUATEMALA. San Marcos, Sibinal, after } \\
\text { the boundary between Guatemala and } \\
\text { Mexico, Tacana vulcano. }\end{array}$ & this article \\
\hline $\begin{array}{l}\text { Physalis pubescens } \\
\text { var. pubescens L. }\end{array}$ & pub & $\begin{array}{l}\text { Knapp } 10609 \\
\text { (BM) }\end{array}$ & PERU. Ancash, Pallasca. & $\begin{array}{l}\text { Deanna et al., } \\
2018\end{array}$ \\
\hline $\begin{array}{l}\text { Physalis solanacea } \\
\text { Mert. ex Roth (as } \\
\text { Margaranthus } \\
\text { solanaceus) }\end{array}$ & sol & $\begin{array}{l}\text { Hernandez s.n. } \\
\text { (accession 519a) }\end{array}$ & $\begin{array}{l}\text { MEXICO. Beween Mexico City and } \\
\text { Queretaro. }\end{array}$ & Menzel, 1950 \\
\hline $\begin{array}{l}\text { Physalis victoriana } \\
\text { J.M.Toledo }\end{array}$ & vic & $\begin{array}{l}\text { Deanna et al. } 363 \\
\text { (CORD) }\end{array}$ & $\begin{array}{l}\text { ARGENTINA. Jujuy, road from } \\
\text { Caimancito to Yuto. }\end{array}$ & This article \\
\hline $\begin{array}{l}\text { Physalis virginiana } \\
\text { Mill. }\end{array}$ & Vir & $\begin{array}{l}\text { Deanna \& Smith } \\
238 \text { (COLO, CORD) }\end{array}$ & $\begin{array}{l}\text { UNITED STATES. Colorado, County } \\
\text { Boulder, South Boulder. }\end{array}$ & This article \\
\hline Physalis viscosa $\mathrm{L}$. & vis & $\begin{array}{l}\text { Chiarini et al. } 911 \\
\text { (CORD) }\end{array}$ & $\begin{array}{l}\text { ARGENTINA. Chaco, Presidencia de La } \\
\text { Plaza. }\end{array}$ & $\begin{array}{l}\text { Deanna et al., } \\
2018\end{array}$ \\
\hline $\begin{array}{l}\text { Quincula lobata } \\
\text { (Torr.) Raf }\end{array}$ & qui & $\begin{array}{l}\text { Deanna, Pretz \& } \\
\text { Carrasco } 232 \\
\text { (COLO, CORD) }\end{array}$ & $\begin{array}{l}\text { UNITED STATES. New Mexico, County } \\
\text { Harding, Ute Creek Valley. }\end{array}$ & this article \\
\hline $\begin{array}{l}\text { Witheringia } \\
\text { coccoloboides } \\
\text { (Dammer) Hunz. }\end{array}$ & wcoc & $\begin{array}{l}\text { Nijmegen. } \\
\text { Accession number } \\
\text { NLD162, } \\
814750081 .\end{array}$ & $\begin{array}{l}\text { COLOMBIA. Quindío, Cajarca, cultivated } \\
\text { at Radboud University. }\end{array}$ & $\begin{array}{l}\text { Deanna et al., } \\
2018\end{array}$ \\
\hline $\begin{array}{l}\text { Witheringia } \\
\text { solanacea L'Hér. }\end{array}$ & wsol & $\begin{array}{l}\text { Leiva González et } \\
\text { al. } 3812 \text { (HAO) }\end{array}$ & $\begin{array}{l}\text { PERU. Cajamarca, San Ignacio, San José } \\
\text { de Lourdes. }\end{array}$ & $\begin{array}{l}\text { Deanna et al., } \\
2018\end{array}$ \\
\hline
\end{tabular}


Table 2. Chromosome data of karyotypically analysed species of Physalidinae: diploid number (2n); satellite pair order number (SAT); karyotype formula; total length of the karyotype haploid chromosome in $\mu \mathrm{m} \pm$ standard deviation (HKL); total mean chromosome length in $\mu \mathrm{m} \pm$ standard deviation (c); range of chromosome length (chr-l); mean arm ratio \pm standard deviation ( $r$ ); ratio between the longest and the shortest chromosome pair $(R)$; intrachromosomal asymmetry index $\left(A_{1}\right)$; interchromosomal asymmetry index $\left(A_{2}\right)$.

\begin{tabular}{|c|c|c|c|c|c|c|c|c|c|c|}
\hline Species & $2 n$ & SAT & HKF & HKL(sd) & c(sd) & chr-1 & $\mathbf{r}(\mathbf{s d})$ & $\mathbf{R}$ & $\mathbf{A 1}$ & A2 \\
\hline A. officinarum var. officinarum & 24 & 1 & $9 m+3 s m$ & $36.27(4.11)$ & $3.02(0.34)$ & $2.68-3.48$ & $1.46(0.06)$ & 1.30 & 0.28 & 0.12 \\
\hline C. coronopus & 48 & 8 and 17 & $5 \mathrm{~m}+6 \mathrm{sm}+1 \mathrm{st}$ & $53.23(8.27)$ & $2.22(0.35)$ & $1.62-2.94$ & $2.06(0.18)$ & 1.81 & 0.36 & 0.18 \\
\hline P. chenopodifolia & 24 & 12 & $6 m+4 s m+2 s t$ & $38.05(2.78)$ & $3.17(0.23)$ & $2.80-3.99$ & $1.87(0.08)$ & 1.43 & 0.36 & 0.15 \\
\hline P. cinerascens var. cinerascens & 24 & 9 & $8 m+3 s m+1 s t$ & $36.01(4.66)$ & $3.00(0.40)$ & $2.14-3.98$ & $1.78(0.28)$ & 1.86 & 0.33 & 0.20 \\
\hline P. cinerascens var. spathulifolia & 24 & - & $7 m+4 s m+1 s t$ & $50.36(3.01)$ & $4.20(0.25)$ & $3.18-5.72$ & $1.77(0.25)$ & 1.80 & 0.34 & 0.21 \\
\hline P. fendleri & 24 & 5 & $8 m+3 s m+1 s t$ & $35.46(3.45)$ & $2.96(0.29)$ & $2.28-3.74$ & $1.67(0.09)$ & 1.64 & 0.33 & 0.20 \\
\hline P. hederifolia & 24 & 9 & $7 m+3 s m+2 s t$ & $37.61(4.69)$ & $3.13(0.39)$ & $2.07-4.07$ & $1.92(0.15)$ & 2.00 & 0.36 & 0.19 \\
\hline P. ixocarpa & 24 & 4 & $6 m+5 s m+1 s t$ & $26.21(3.46)$ & $2.18(0.29)$ & $1.80-2.64$ & $1.84(0.16)$ & 1.47 & 0.39 & 0.16 \\
\hline P. lagascae & 24 & - & $9 \mathrm{sm}+3 \mathrm{st}$ & $29.99(5.33)$ & $2.50(0.44)$ & $2.06-3.00$ & $2.77(0.16)$ & 1.46 & 0.58 & 0.13 \\
\hline P. longifolia & 24 & 8 & $3 m+7 s m+2 s t$ & $20.00(5.02)$ & $1.67(0.42)$ & $1.34-2.13$ & $2.25(0.52)$ & 1.60 & 0.49 & 0.16 \\
\hline P. peruviana & 48 & 20 & $12 \mathrm{~m}+10 \mathrm{sm}+1 \mathrm{st}+1 \mathrm{t}$ & $48.26(15.90)$ & $2.01(0.66)$ & $1.08-2.58$ & $2.23(0.32)$ & 2.38 & 0.34 & 0.19 \\
\hline P. philadelphica & 24 & 2 & $6 m+5 s m+1 s t$ & $31.05(3.29)$ & $2.59(0.27)$ & $2.16-3.17$ & $1.81(0.11)$ & 1.48 & 0.38 & 0.15 \\
\hline P. porrecta & 24 & 5 & $5 \mathrm{~m}+5 \mathrm{sm}+2 \mathrm{st}$ & $27.51(5.41)$ & $2.29(0.45)$ & $1.73-2.98$ & $1.89(0.28)$ & 1.72 & 0.40 & 0.20 \\
\hline P. pubescens & 48 & 6 and 19 & $13 m+9 s m+1 s t+1 t$ & $60.27(5.49)$ & $2.51(0.23)$ & $1.65-3.26$ & $2.36(0.29)$ & 1.98 & 0.32 & 0.19 \\
\hline P. victoriana & 24 & 10 & $5 \mathrm{~m}+6 \mathrm{sm}+1 \mathrm{st}$ & $19.39(1.94)$ & $1.62(0.16)$ & $1.37-1.91$ & $1.86(0.22)$ & 1.40 & 0.40 & 0.12 \\
\hline$P$. virginiana & 24 & 3 & $3 m+8 s m+1 s t$ & $23.87(2.03)$ & $3.12(0.17)$ & $1.90-2.56$ & $2.02(0.19)$ & 1.35 & 0.48 & 0.11 \\
\hline P. viscosa & 24 & 11 & $6 m+5 s m+1 s t$ & $38.95(3.36)$ & $3.25(0.28)$ & $2.90-3.74$ & $1.87(0.11)$ & 1.29 & 0.40 & 0.14 \\
\hline Q. lobata & 44 & - & $6 m+13 s m+3 s t$ & $44.91(3.35)$ & $2.04(0.15)$ & $1.84-3.16$ & $2.08(0.17)$ & 1.72 & 0.43 & 0.18 \\
\hline
\end{tabular}


Table. 3. Summary of the Stochastic Character Mapping for discrete chromosome features. (TC) mean number of total changes; (C) median number of changes per transition; ( $95 \% \mathrm{Cl}$ ) $95 \%$ credibility interval of number of changes. Most frequent transitions are in bold.

\begin{tabular}{|c|c|c|c|c|c|c|c|c|}
\hline Trait & $\begin{array}{l}\text { Mod } \\
\text { el }\end{array}$ & Character states & $\mathrm{TC}$ & $\begin{array}{c}\text { TC }(95 \% \\
\mathrm{Cl})\end{array}$ & $\begin{array}{l}\text { Trans } \\
\text { ition }\end{array}$ & $\mathrm{C}$ & $\begin{array}{l}\text { C }(95 \% \\
\mathrm{Cl})\end{array}$ & $\begin{array}{c}\text { State at the } \\
\text { Physalidinae root }\end{array}$ \\
\hline \multirow[t]{6}{*}{$\begin{array}{l}\text { Submetacentric } \\
\text { chromosomes }\end{array}$} & ARD & $0=$ up to three pairs & 23 & $\begin{array}{c}12.40- \\
36.39\end{array}$ & $0>1$ & 4 & $0-10.00$ & 0 \\
\hline & & $\begin{array}{l}1=\text { between four } \\
\text { and six pairs }\end{array}$ & & & $0>2$ & 1 & $0-5.23$ & \\
\hline & & $\begin{array}{l}2 \text { = seven or more } \\
\text { pairs }\end{array}$ & & & $1>0$ & 10 & $\begin{array}{l}1.93- \\
21.05\end{array}$ & \\
\hline & & & & & $1>2$ & 6 & $\begin{array}{l}1.80- \\
10.72\end{array}$ & \\
\hline & & & & & $2>0$ & 1 & $0-6.82$ & \\
\hline & & & & & $2>1$ & 1 & $0-3.71$ & \\
\hline \multirow[t]{6}{*}{$\begin{array}{l}\text { Subtelocentric } \\
\text { chromosomes }\end{array}$} & ARD & $0=$ absence & 22 & $\begin{array}{c}12.97- \\
31.28\end{array}$ & $0>1$ & 3 & $0-5.70$ & 0 \\
\hline & & 1 = one pair & & & $0>2$ & 1 & $0-3.26$ & \\
\hline & & $2=$ two or more pairs & & & $1>0$ & 0 & $0-7.37$ & \\
\hline & & & & & $1>2$ & 15 & $0-21.13$ & \\
\hline & & & & & $2>0$ & 0 & $0-6.61$ & \\
\hline & & & & & $2>1$ & 3 & $0-16.69$ & \\
\hline
\end{tabular}


Table. 4. Summary of phylogenetic signal (Blomberg's K) for continuous chromosome traits. PICs: phylogenetically independent contrasts relative to tip shuffling randomization. P-values indicate whether the K-value is significantly different from zero (no phylogenetic signal) and/or from one (signal expected under Brownian Motion). P-values less than 0.05 are bolded.

\begin{tabular}{|c|c|c|c|c|}
\hline Trait & $\begin{array}{c}\lambda \text { (Pagel, } \\
\text { 1999) }\end{array}$ & $\begin{array}{c}\text { Blomberg's } \\
\text { K }\end{array}$ & $\begin{array}{c}\text { P-value of observed vs. random } \\
\text { variance of PICs P-value of } \\
\text { observed vs. random variance } \\
\text { of PICs } \\
\text { (<0.05 means K significantly } \\
\text { different to zero) }\end{array}$ & $\begin{array}{c}\text { P-value of observed vs. } \\
\text { random variance of PICs P- } \\
\text { value of observed vs. random } \\
\text { variance of PICs } \\
\text { (<0.05 means } \mathrm{K} \text { significantly } \\
\text { different to one) }\end{array}$ \\
\hline A1 & 0.99 & 1.23 & 0.0001 & 0.74 \\
\hline$A 2$ & 0.94 & 0.89 & 0.0005 & 0.86 \\
\hline$r$ & 0.91 & 1.02 & 0.0001 & 0.98 \\
\hline c & 0.42 & 0.52 & 0.06 & 0.20 \\
\hline
\end{tabular}




\section{References}

Acosta, M. C., Bernardello, G., Guerra, M., \& Moscone, E. A. (2005). Karyotype analysis in several South American species of Solanum and Lycianthes rantonnei (Solanaceae). Taxon, 54(3), 713-723.

Akaike, H. (1974). A new look at the statistical model identification. IEEE Transactions on Automatic Control, 19(6), 716-723.

Averett, J. E. (1973). Biosystematic study of Chamaesaracha (Solanaceae). Rhodora, 75(803), 325365.

Badr, A., Khalifa, S. F., Aboel Atta, A. I., \& Abou el Enain, M. M. (1997). Chromosomal criteria and taxonomic relationships in the Solanaceae. Cytologia, 62(1), 103-113.

Baltisberger, M., \& Hörandl, E. (2016). Karyotype evolution supports the molecular phylogeny in the genus Ranunculus (Ranunculaceae). Perspectives in Plant Ecology, Evolution and Systematics, 16, 1-14.

Banks, P. (1984). A new diploid chromosome number for tomato (Lycopersicon esculentum)? Canadian Journal of Genetics and Cytology, 26(5), 636-639.

Barboza, G. E. (2000). Rehabilitación del género Quincula (Solanaceae: Solaneae). Kurtziana, 28(1), 69-79.

Barboza, G. E., Chiarini, F. E., \& Stehmann, J. R. (2010). Real identity of Witheringia sellowiana (Solanaceae), typification, and chromosome number. Systematic Botany, 35, 420-424.

Barboza, G. E., Hunziker, A. T., Bernardello, G., Cocucci, A. A., Carrizo García C., Fuentes V., Dillon, M., Bittrich, V., Cosa, M. T., Subils, R., Romanutti, A., Arroyo, S., \& Anton, A. (2016). Solanaceae. In K. Kubitzki (Ed.). The Families and Genera of Vascular Plants, 14, 295-357.

Battaglia, E. (1955). Chromosome morphology and terminology. Caryologia, 8, 179-187.

Blöch, C., Weiss-Schneeweiss, H., Schneeweiss, G. M., Barfuss, M. H., Rebernig, C. A., Villaseñor, J. L., \& Stuessy, T. F. (2009). Molecular phylogenetic analyses of nuclear and plastid DNA sequences support dysploid and polyploid chromosome number changes and reticulate evolution in the diversification of Melampodium (Millerieae, Asteraceae). Molecular Phylogenetics and Evolution, 53(1), 220-233.

Blomberg, S. P., Garland, Jr. T., \& Ives, A. R. (2003). Testing for phylogenetic signal in comparative data: behavioral traits are more labile. Evolution, 57(4), 717-745.

Bohs, L. (2005). Major clades in Solanum based on $n d h F$ sequence data. In V. Hollowell , R. Keating, W. Lewis \& T. Croat (Eds.). A Festschrift for William D'Arcy. Monographs in Systematic Botany from the Missouri Botanical Garden (vol. 104, pp. 24-49). St. Louis, MO: Missouri Botanical Garden Press.

Brako, L., \& Zarucchi, J. (1993). Catalogue of the flowering plants and Gymnosperms of Peru. Catálogo de las Angiospermas y Gimnospermas del Perú. Monographs in systematic botany from the Missouri Botanical Garden, 45, 1-1286.

Brandham, P. E., \& Doherty, M. J. (1998). Genome size variation in the Aloaceae, an angiosperm family displaying karyotypic orthoselection. Annals of Botany, 82, 67-73.

Brown, J. H. (1984). On the relationship between distribution and abundance. American Naturalist, 124, 255-279.

Chiarini, F. E., \& Barboza, G. E. (2008). Karyological studies in Jaborosa (solanaceae). Botanical Journal of the Linnean Society, 156(3), 467-478. 
Chiarini, F. E., Moreno, N., Barboza, G. E., \& Bernardello, G. (2010). Karyotype characterization of Andean Solanoideae (Solanaceae). Caryologia, 63, 278-291.

Chiarini, F. E., Lipari, D., Barboza, G. E. \& Knapp, S. (2017). Solanaceae. In: Marhold, K. \& J. Kučera (Eds.). IAPT/IOPB chromosome data 25. Taxon, 66(5), 1246-1252.

Chiarini, F. E., Sazatornil, F., \& Bernardello, G. (2018). Data reassessment in a phylogenetic context gives insight into chromosome evolution in the giant genus Solanum (Solanaceae). Systematic and Biodiversity, 16(4), 1-20.

Deanna, R., Barboza, G. E., \& Scaldaferro, M. A. (2014). First karyological report in Larnax and Deprea (Solanaceae). Australian Journal of Botany, 62, 251-261.

Deanna, R., Smith, S. D., Särkinen, T., \& Chiarini, F. E. (2018). Patterns of chromosomal evolution in the florally diverse Andean clade lochrominae (Solanaceae). Perspectives in Plant Ecology, Evolution and Systematics, 35, 31-43.

Deanna, R., Larter, M. D., Barboza, G. E., \& Smith, S. D. (2019). Repeated evolution of a morphological novelty: a phylogenetic analysis of the inflated fruiting calyx in the Physalideae tribe (Solanaceae). American Journal of Botany, 106(2), 270-279.

Ellis, R. H., Hong, T. D., \& Roberts, E. H. (1985). Compendium of specific germination, information and test recommendations. Handbook for Genebanks 3. Rome: International Board for Plant Genetic Resources.

FitzJohn, R. G. (2012). Diversitree: comparative phylogenetic analyses of diversification in R. Methods in Ecology and Evolution, 3, 1084-1092.

Futuyma, D. J. (2005). Evolution (3rd ed.). Sunderland, MA: Sinauer Associates, Inc. Publishers.

Glick, L., \& Mayrose, I. (2014). ChromEvol: assessing the pattern of chromosome number evolution and the inference of polyploidy along a phylogeny. Molecular Biology and Evolution, 31(7), 1914-1922.

Goldblatt, P., \& Johnson, D. E. (1979, onwards). Index to plant chromosome numbers. St. Louis: Missouri Botanical Garden. Retrieved from http://www.tropicos.org/Project/ IPCN (accessed 17 August 2019).

Guerra, M. (2012). Cytotaxonomy: The end of childhood. Plant Biosystems, 146(3), 703-710.

Hegarty, M. J., \& Hiscock, S. J. (2008). Genomic clues to the evolutionary success of review polyploid plants. Current Biology, 18(10), 435-444.

Huelsenbeck, J. P., Nielsen, R., \& Bollback, J. P. (2003). Stochastic mapping of morphological characters. Systematic Biology, 52(2), 131-158.

Kembel, S. W., Cowan, P. D., Helmus, M. R., Cornwell, W. K., Morlon, H., Ackerly, D. D., Blomberg, S. P., \& Webb, C. O. (2010). Picante: R tools for integrating phylogenies and ecology. Bioinformatics 26(11): 1463-4. doi: 10.1093/bioinformatics/btq166.

Leitch, I. J., \& Bennett, M. D. (2004). Genome downsizing in polyploid plants. Biological journal of the Linnean Society, 82(4), 651-663.

Levan, A., Fredga, L., \& Sandberg, A. (1964). Nomenclature for centromeric position on chromosomes. Hereditas, 52, 201-220.

Levin, D. A. (2003). The ecological transition in speciation. New Phytologist, 161, 91-96.

Levin, D. A., \& Funderburg, S. W. (1979). Genome size in angiosperms: temperate versus tropical species. The American Naturalist, 114(6), 784-795. 
Li, H.Q., Gui, P., Xiong, S.Z., \& Averett, J.E. (2013). The generic position of two species of tribe Physaleae (Solanaceae) inferred from three DNA sequences: a case study on Physaliastrum and Archiphysalis. Biochemical Systematic Ecology, 50, 82-89.

Madlung, A. (2013). Polyploidy and its effect on evolutionary success: old questions revisited with new tools. Heredity, 110(2), 99-104.

Mandáková, T., \& Lysak, M. A. (2008). Chromosomal phylogeny and karyotype evolution in x= 7 crucifer species (Brassicaceae). The Plant Cell, 20(10), 2559-2570.

Maxime, V. (2008) The physiology of triploid fish: Current knowledge and comparisons with diploid fish. Fish and Fisheries, 9(1), 67-78.

Mayrose, I., Barker, M. S., \& Otto, S. P. (2010). Probabilistic models of chromosome number evolution and the inference of polyploidy. Systematic Biology, 59(2), 132-144.

Menzel, M. Y. (1950). Cytotaxonomic observations on some genera of the Solanae: Margaranthus, Saracha, and Quincula. American Journal of Botany, 37, 25-30.

Menzel, M. Y. (1951). The cytotaxonomy and genetics of Physalis. Proceedings of the American Philosophical Society, 95(2), 132-183.

Moscone, E. A. (1992). Estudios de cromosomas meióticos en Solanaceae de Argentina. Darwiniana, 31, 261-297.

Moscone, E. A., Baranyi, M., Ebert, I., Greilhuber, J., Ehrendorfer, F., \& Hunziker, A. T. (2003). Analysis of nuclear DNA content in Capsicum (Solanaceae) by flow cytometry and Feulgen densitometry. Annals of Botany, 92(1), 21-29.

Moscone, E. A., Scaldaferro, M. A., Grabiele, M., Cecchini, N. M., Sánchez García, Y., Jarret, R., \& Ehrendorfer, F. (2006). The evolution of chili peppers (Capsicum-Solanaceae): a cytogenetic perspective. In VI International Solanaceae Conference: Genomics Meets Biodiversity. Acta Horticulturae 745, 137-170.

Nielsen, R. (2001). Mutations as missing data: inferences on the ages and distributions of nonsynonymous and synonymous mutations. Genetics, 159(1), 401-411.

Olmstead, R. G., \& Bohs, L. (2006). A summary of molecular systematic research in Solanaceae: 1982-2006. In VI International Solanaceae Conference: Genomics Meets Biodiversity. Acta Horticulturae 745, 255-268.

Olmstead, R. G., Bohs, L., Migid, H. A., Santiago Valentin, E., Garcia, V. F., \& Collier, S. M. (2008). A molecular phylogeny of the Solanaceae. Taxon, 57(4), 1159-1181.

Otto, S. P., \& Whitton, J. (2000). Polyploid incidence and evolution. Annual Review of Genetics, 34, 401-437.

Pagel, M. (1999). Inferring the historical patterns of biological evolution. Nature, 401(6756), 877.

Paradis, E., Claude, J., \& Strimmer, K. (2004). APE: analyses of phylogenetics and evolution in R language. Bioinformatics, 20(2), 289-290.

Poggio, L. (1996). Algunos aportes a la citogenética y especiación vegetal. Anales de la Academia Nacional de Ciencias Exactas, Físicas y Naturales. Buenos Aires, Argentina, 48, 79-92.

Poggio, L., Realini, M. F., Fourastié, M. F., García, A.M., \& González, G. E. (2014). Genome downsizing and karyotype constancy in diploid and polyploid congeners: a model of genome size variation. AoB PLANTS 6: plu029; doi:10.1093/aobpla/plu029

Pound, G. E., Cox, S. J., \& Doncaster, C. P. (2004). The accumulation of deleterious mutations within the frozen niche variation hypothesis. Journal of Evolutionary Biology, 17(3), 651662. 
Pretz, C., \& Deanna, R. (2020). Typifications and nomenclatural notes in Physalis (Solanaceae) from the United States. Taxon, early view.

R Core Team (2017). R: A Language and Environment for Statistical Computing (R Foundation for Statistical Computing, 2016). Retrieved from: https://www.R-project.org (Accessed 01 August 2019).

Ranney, T. G. (2006). Polyploidy: From evolution to new plant development. Combined Proceedings International Plant Propagators' Society, 56, 137-142.

Rego, L. N. A. A., da Silva, C. R. M., Torezan, J. M. D., Gaeta, M. L., \& Vanzela, A. L. L. (2009). Cytotaxonomical study in Brazilian species of Solanum, Lycianthes and Vassobia (Solanaceae). Plant Systematics and Evolution, 279, 93-102.

Revell, L. J. (2012). Phytools: an R package for phylogenetic comparative biology (and other things). Methods in Ecology and Evolution, 3, 217-223.

Rice, A., Glick, L., Abadi, S., Einhorn, M., Kopelman, N. M., Salman Minkov, A., \& Mayrose, I. (2015). The Chromosome Counts Database (CCDB) - a community resource of plant chromosome numbers. New Phytologist, 206(1), 19-26.

Rodríguez, N. C., \& Bueno, M. L. (2006). Estudio de la diversidad citogenética de Physalis peruviana L. (Solanaceae). Acta Biológica Colombiana, 11(2), 75-85.

Romero Zarco, C. (1986). A new method for estimating karyotype asymmetry. Taxon, 35(3), 526530.

Särkinen, T., Bohs, L., Olmstead, R. G., \& Knapp, S. (2013). A phylogenetic framework for evolutionary study of the nightshades (Solanaceae): a dated 1000-tip tree. BMC Evolutionary Biology, 13(1), 214.

Sattler, M. C., Carvalho, C. R., \& Clarindo, W. R. (2016). The polyploidy and its key role in plant breeding. Planta, 243(2), 281-296.

Schneider, C. A., Rasband, W. S., \& Eliceiri, K. W. (2012). "NIH Image to ImageJ: 25 years of image analysis", Nature methods, 9(7), 671-675.

Schönswetter, P., Lachmayer, M., Lettner, C., Prehsler, D., Rechnitzer, S., Reich, D. S., \& Trávníček, P. (2007). Sympatric diploid and hexaploid cytotypes of Senecio carniolicus (Asteraceae) in the Eastern Alps are separated along an altitudinal gradient. Journal of Plant Research, 120(6), 721-725.

Sheehan, D., \& Hrapchak, B. (1980). Theory and practice of Histotechnology (2nd ed.). St Louis, MO: The CV Mosby Company.

Smith, S. D., \& Baum, D. A. (2006). Phylogenetics of the florally diverse Andean clade lochrominae (Solanaceae). American Journal of Botany, 93, 1140-1153.

Soltis, D. E., Soltis, P. S., Pires, J. C., Kovarik, A., Tate, J. A., \& Mavrodiev, E. (2004). Recent and recurrent polyploidy in Tragopogon (Asteraceae): cytogenetic, genomic and genetic comparisons. Biological Journal of the Linnean Society, 82(4), 485-501.

Sousa Peña, M. (2001). Systematics and reproductive biology of the genus Whiteringia L' Hér. (Solanaceae). Unpublished D. Phil. Thesis, University of Connecticut, Storrs, CT.

Stace, C. A. (2000). Cytology and cytogenetics as a fundamental taxonomic resource for the 20th and 21st centuries. Taxon, 49(3), 451-477.

Stebbins, G. L. (1971). Chromosomal Evolution in Higher Plants. London, UK: E. Arnold.

Stebbins, G. L. (1985). Polyploidy, hybridization, and the invasion of new habitats. Annals of the Missouri Botanical Garden, 72(4), 824-832. 
Stiefkens, L., \& Bernardello, G. (2000). Karyotypes and DNA content in diploid and polyploid Lycium (Solanaceae). Boletín de la Sociedad Argentina de Botánica, 35, 237-244.

Thorpe, P. H., González Barrera, S., \& Rothstein, R. (2007). More is not always better: the genetic constraints of polyploidy. Trends in Genetics, 23(6), 263-266.

Toledo, J. M., \& Barboza G. E. (2013). Physalis L. In F. O. Zuloaga, M. Belgrano \& A. M. Anton (Eds.). Flora Argentina: Solanaceae. (vol. 13, pp. 141-148). San Isidro, Buenos Aires: IBODAIMBIV, CONICET.

Udall, J. A., \& Wendel, J. F. (2006). Polyploidy and crop improvement. Crop Science, 46 (Supplement 1), S-3.

Venkateswarlu, J., \& Raja Rao, K. G. (1977). Morphology of the pachytene chromosomes of Physalis philadelphica Lam. Caryologia, 30(4), 435-440.

Venkateswarlu, J., \& Raja Rao, K. G. (1979a). Morphology of the pachytene chromosomes of Physalis pubescens L. Cytologia, 44(1), 161-166.

Venkateswarlu, J., \& Raja Rao, K. G. (1979b). Morphology of the pachytene chromosomes of Physalis angulata L. Cytologia, 44(3), 557-560.

Weiss Schneeweiss, H., \& Schneeweiss, G. M. (2013). Karyotype diversity and evolutionary trends in angiosperms. In I. J. Leitch (Ed.). Plant Genome Diversity, 2, 209-230.

Winchester, A. M. (1981). Genética (3rd ed.) México: Compañía Editorial Continental.

Whitson, M., \& Manos, P. S. (2005). Untangling Physalis (Solanaceae) from the Physaloids: A TwoGene Phylogeny of the Physalinae. Systematic Botany, 30(1), 216-230.

Whittemore, A. T., \& Olsen, R. T. (2011). Ulmus americana (Ulmaceae) is a polyploid complex. American Journal of Botany, 98(4), 754-760.

Wu, F., \& Tanksley, S. D. (2010). Chromosomal evolution in the plant family Solanaceae. BMC genomics, 11(1), 182.

Yamazaki, T. (1993). Solanaceae. In K. Iwatsuki, T. Yamazaki, D. E. Boufford / H. Ohba (Eds.). Flora of Japan (pp. 183-194). Illa, Tokyo: Kodansha Ltd.

Yu, Y., Harris, A.J., Blair, C., \& He, X. (2015). RASP (Reconstruct Ancestral State in Phylogenies): a tool for historical biogeography. Molecular Phylogenetics and Evolution, 87, 46-49.

Zamora Tavares, M. P., Martínez, M., Magallón, S., Guzmán Dávalos, L., \& Vargas Ponce, O. (2016). Physalis and physaloids: A recent and complex evolutionary history. Molecular phylogenetics and evolution, 100, 41-50.

Zhang, Z. Y., Lu, A. M., \& D’Arcy, W. G. (1994). Solanaceae. In Z.Y. Wu \& P.H. Raven (Eds.). Flora of China (vol. 17, pp. 300-332) St. Louis, MO: Missouri Botanical Garden Press. 